\title{
Oral manifestations detected in COVID-19 patients: an integrative review
}

\author{
Manifestações orais detectadas em pacientes com COVID-19: uma revisão integrativa \\ Manifestaciones orales detectadas en pacientes con COVID-19: una revisión integradora
}

Received: 10/29/2021 | Reviewed: 11/07/2021 | Accept: 11/09/2021| Published: 11/14/2021

\author{
Iago Ramirez \\ ORCID: https://orcid.org/0000-0001-8266-1352 \\ Universidade Federal de Alfenas, Brazil \\ E-mail: iagoramirez01@gmail.com \\ Lélio Fernando Ferreira Soares \\ ORCID: https://orcid.org/0000-0003-4174-2943 \\ Universidade Federal de Alfenas, Brazil \\ E-mail: lelio.soares@ sou.unifal-mg.edu.br \\ Marcela de Come Ramos \\ ORCID: https://orcid.org/0000-0002-6041-6329 \\ Universidade Federal de Alfenas, Brazil \\ E-mail: marcela.ramos@sou.unifal-mg.edu.br \\ Marcela Filié Haddad Danziger \\ ORCID: https://orcid.org/0000-0003-3455-6624 \\ Universidade Federal de Alfenas, Brazil \\ E-mail: marcela.haddad@unifal-mg.edu.br
}

\begin{abstract}
The aim of this integrative review consisted of verifying whether the oral manifestations detected in patients diagnosed with COVID-19 are useful in diagnosing the disease, whether they are a manifestation resulting from the disease, or whether there is evidence that there is no correlation between the pathologies. Therefore, articles in the PubMed, Lilacs, Scopus, Science Direct, Web of Science and Embase databases were searched, in addition to the search in gray literature. The terms used in the search were: "COVID-19" or "Sars-Cov-2" or "coronavirus" and "oral conditions" or "oral health" or "oral manifestations" and "diagnosis/complications" or "symptoms". Thus, 1.305 articles were selected, of which 61 were selected to compose this review. Most of the included studies considered oral symptoms as taste changes, xerostomia and ulcerative lesions in the oral and labial mucosa. All symptoms related to this pathology still need further studies and investigations so that all mechanisms and manifestations related to it are completely elucidated.
\end{abstract}

Keywords: Coronavirus infections; Oral manifestations; Pathology, oral.

\section{Resumo}

O objetivo desta revisão integrativa consistiu em verificar se as manifestações bucais detectadas em pacientes com diagnóstico de COVID-19 são úteis no diagnóstico da doença, ou se são manifestações decorrentes da doença, ou ainda, se há evidências de que não há correlação entre as patologias. Para tanto, foram pesquisados artigos nas bases de dados PubMed, Lilacs, Scopus, Science Direct, Web of Science e Embase, além de uma busca na literatura cinzenta. Os termos utilizados na busca foram: "COVID-19" ou "Sars-Cov-2" ou "coronavírus" e "condições bucais" ou "saúde bucal" ou "manifestações orais" e "diagnóstico / complicações" ou "sintomas". Assim, foram localizados 1.305 artigos, dos quais 61 foram selecionados para compor esta revisão. A maioria dos estudos incluídos considerou sintomas orais como alterações do paladar, xerostomia e lesões ulcerativas na mucosa oral e labial. Todos os sintomas relacionados a essa patologia ainda precisam de mais estudos e investigações para que os mecanismos e manifestações a ela relacionados sejam completamente elucidados.

Palavras-chave: Infecções por coronavírus; Manifestações bucais; Patologia bucal.

\section{Resumen}

El objetivo de esta revisión integradora consiste en verificar si las manifestaciones orales detectadas en pacientes con COVID-19 son útiles en el diagnóstico de la enfermedad, si son una manifestación resultante de la enfermedad o si existe evidencia de que no existe correlación entre las patologías. Se realizaron búsquedas de artículos en las bases de datos PubMed, Lilacs, Scopus, Science Direct, Web of Science y Embase, además de la búsqueda en literatura gris. Los términos utilizados en la búsqueda fueron: "COVID-19" o "Sars-Cov-2" o "coronavirus" y "afecciones bucales" o "salud bucal" o "manifestaciones bucales" y "diagnóstico / complicaciones" o "síntomas". Así, se seleccionaron 1305 artículos, de los cuales se seleccionaron 61 para componer esta revisión. La mayoría de los estudios incluidos consideraron los síntomas orales como cambios en el gusto, xerostomía y lesiones ulcerativas en la mucosa oral y labial. Todos los 
síntomas relacionados con esta patología aún necesitan más estudios e investigaciones para que se esclarezcan por completo todos los mecanismos y manifestaciones relacionados con ella.

Palabras clave: Infecciones por Coronavirus; Manifestaciones bucales; Patología bucal.

\section{Introduction}

On March 11, 2020, Coronavirus Disease (COVID-19) was declared a pandemic situation by the World Health Organization (WHO) (Osseni, 2020). It is a disease caused by SARs-CoV-2, discovered in 2019 in China with the occurrence of the first cases of the disease. It has had a fast progression throughout the years 2020 and 2021 with more than 203 million infected people around the world, spread over 215 countries (Khan et al., 2020). On August 2021, the main countries affected is: the United States of America (35.824.366 confirmed cases), India (240.842 confirmed cases), Brazil (20.177.757 confirmed cases) and the Russian Federation (11.012 confirmed cases) (WHO, 2021). To date, the profile of viral action and pathogenesis has not been fully elucidated, but it is known that the main signs and symptoms manifest themselves in the form of acute respiratory conditions (Ali \& Alharbi, 2020). However, new characteristics emerge from time to time, and the lack of complete knowledge of the disease's etiopathogenesis associated with its potential risk of death and high probability of contagion form the set that characterizes COVID-19 as perhaps the greatest health crisis of the current century (Alvi et al., 2020; Lai et al., 2020; Osseni, 2020).

The epidemiological profile so far is the prevalence of symptom onset in men, with a mean age of 56 years (Huang et al., 2020), with the onset of symptoms within 8 days (which may vary from 5 to 13) after contact with the virus (Guan et al., 2020), and increased risk of death associated with older adults over 80 years of age (Wilson et al., 2020). Several comorbidities are associated with an unfavorable prognosis for the course of the disease, the main ones being cardiovascular diseases, hypertension, diabetes, chronic inflammatory diseases and the abusive habit of smoking (Ejaz et al., 2020).

The predominant form of contagion is direct contact, which can also happen indirectly and through the air when contaminated by aerosols (Umakanthan et al., 2020). Most of the symptoms presented are nonspecific (such as fever, cough and myalgia), and the course of the disease can follow a mild to moderate route (with and without pneumonia), severe (presence of dyspnea and respiratory distress) or critical (failure respiratory and even multiple organ failure), with rapid evolution and in many cases unpredictable (Raoult et al., 2020).

Even though acute pneumonia and respiratory manifestations were the first sign of the disease's challenge (Khan et al., 2020), today other systemic manifestations are directly associated with COVID-19 (Lai et al., 2020; Wiersinga et al., 2020). Cardiac, gastrointestinal, hepatic, renal, neurological, olfactory and taste, ocular, cutaneous, hematological and immunological conditions and/or sequelae are already mentioned (Lai et al., 2020; Yang et al., 2020). They are cited as uncommon occurrences, but not rare in patients who went through the hospitalization process, coagulopathies, thromboembolic accidents, heart disease, hemodynamic instability and encephalopathies (Hendren et al., 2020; Long et al., 2020; Mao et al., 2020; Middeldorp et al., 2020; Wiersinga et al., 2020). In this context, it is important to emphasize the systemic inflammatory favoritism, directly associated with COVID-19, in which pre-existing chronic inflammatory conditions find room for acute and more intense manifestations, as well as the manifestation of more severe forms of COVID-19 itself (Zeng et al., 2020).

In addition to systemic manifestations, some oral manifestations have also been reported (Sinjari, D'ardes, et al., 2020). Not restricted only to olfactory disorders and taste disorders, already directly associated with COVID-19, others involving oral mucosa, glossitis and gingival inflammation are reported, mainly in hospitalized patients (Amorim dos Santos et al., 2020a). However, despite the reports, there is still no clinical consensus on which mechanisms are responsible for the manifestations, whether they are causes directly linked to the course of COVID-19 or events secondary to it, and even whether they can serve as a form of diagnosis (Iranmanesh et al., 2021a). The presence of bullous lesions, ulcerations, erosions, plaques and macules 
was noticed in different regions of the mucosa and under different clinical presentations (Amorim dos Santos et al., 2020a) such as transient lingual papillitis, mucositis, glossitis, aphthous stomatitis, burning sensation in the mouth, among others (Iranmanesh et al., 2021a; Nuno-Gonzalez et al., 2021; Sinjari, D’ardes, et al., 2020). Due to the existence of gaps in the literature regarding the understanding of this relationship between COVID-19 and oral health, and regarding the role of the dentist in monitoring these manifestations and the clinical evolution of patients, this review finds space and justification for its realization.

To assess, through an integrative literature review, whether the oral manifestations detected in patients diagnosed with COVID-19 are useful in the diagnosis of the disease, whether they are a manifestation resulting from the disease, or whether there are signs of no correlation between the pathologies.

\section{Methodology}

\section{Study design and eligibility criteria}

This is an integrative review, carried out in accordance with the PRISMA checklist (Page et al., 2021), and registered within PROSPERO (CRD42021253256). The review guiding question is "Is COVID-19 cause or consequence of changes in the pattern of oral health?", and based on that, the PICO strategy is specified in Table 1, with the eligibility criteria.

Table 1. PICO Strategy.

\begin{tabular}{|c|c|c|}
\hline Domain & Inclusion criteria & Exclusion criteria \\
\hline Participants & Adult patients diagnosed with COVID-19. & $\begin{array}{l}\text { Children patients confirmed for COVID-19, and } \\
\text { patients not diagnosed with COVID-19. }\end{array}$ \\
\hline Interventions & $\begin{array}{l}\text { Intraoral exam and test or clinical evaluation to assess } \\
\text { the confirmation for SARS-CoV-2 presence and/or the } \\
\text { COVID-19. }\end{array}$ & $\begin{array}{l}\text { Non-realization of intraoral exam, absence of test or } \\
\text { clinical evaluation to diagnose the COVID-19. }\end{array}$ \\
\hline Comparisons & Patients with and without oral manifestations & \\
\hline Outcomes & Presence of oral manifestations. & $\begin{array}{l}\text { Absence of any kind of oral manifestation associated } \\
\text { with COVID-19. }\end{array}$ \\
\hline Study design & $\begin{array}{c}\text { Randomized clinical trials, observational cohort } \\
\text { studies, clinical reports, reviews, case-control studies } \\
\text { and case series. }\end{array}$ & $\begin{array}{l}\text { Mini-reviews, laboratory studies (in vivo, in vitro and } \\
\text { ex vivo) and all kinds of publications different from } \\
\text { articles published in scientific journals. }\end{array}$ \\
\hline
\end{tabular}

Source: Authors.

The inclusion criteria were defined via the PICO strategy and consisted of randomized control trials (RCTs), observational cohort studies (prospective or retrospective), literature reviews (narrative, integrative or systematic), clinical reports, case-control studies, or case series that included adult participants with COVID-19 infection and oral manifestations were included. There was no language restriction, and the papers that could not be accessed in the full-text version were excluded.

Therefore, the literature search was conducted using a single search engine through PubMed, Lilacs, Scopus, Science Direct, Web of Science, and Embase databases. An additional search in the gray literature was performed, including Google Scholar. The search included all articles published until March 24, 2021, across all databases. To identify eligible articles, using the Medical subject headings (MeSH) "COVID-19" or "Sars-Cov-2" or "coronavirus" and "oral conditions" or "oral health" or "oral manifestations" and "diagnosis/complications" or "symptoms", using Boolean operators. The publication time was limited to 2019 onward, to assess the pandemic time course.

A free-web tool for review management (Rayyan QCRI®) (Ouzzani et al., 2016) was used to collect references and remove duplicate articles. The same search strategies will be run on every update. 
Initially, broad screening was conducted according to the title and abstracts under the use of the tool Rayyan (Ouzzani et al., 2016). In the end, all potentially included articles were retrieved for a full assessment and those that could be accessed were reviewed in full length to be verified if they were answering the eligibility criteria. Translation of included papers from Chinese to English was conducted with the use of Google Chrome's built-in translation tool.

\section{Data Extraction}

Two reviewers (XX and XX) separately assessed the potentially included papers to verify eligibility. Discrepancies were resolved by a third reviewer (XX). Those three reviewers were supported by a fourth (XX) to accomplish the data extraction. The main information to be extracted was related to the clinical conditions of the COVID-19 course, and any oral manifestations reported (ulceration, erosion, plaque, macules, bullous lesions, dysgeusia, mucositis, glossitis, burning mouth sensation, and others). This data extraction was based on information about the incidence and prevalence of oral manifestations detected on patients confirmed for COVID-19, in a way that all percentages and samples sizes, clinical states reported, the severity of the disease, moment of evaluation, and other relevant clinical data was also important to be summarized. All data extracted from the papers were tabulated on a unique sheet on Google Docs, simultaneously fed by the reviewers, seeking out the favoring of the qualitative synthesis.

\section{Results}

The literature search resulted in 1305 hits. After the removal of the duplicates, broad screening by title and abstract, retrieval of those selected for appraisal and critical evaluation by eligibility criteria in full-text version, and assessment in full length of them, 61 papers composed the sample of this review, for qualitative synthesis (Supplementary Table 1). The PRISMA flow diagram detailing the steps of identification, screening, and inclusion is available in Figure 1. 
Figure 1. illustrates the Prisma flowchart that details the entire sequence of location, identification and final inclusion of the 61 articles.

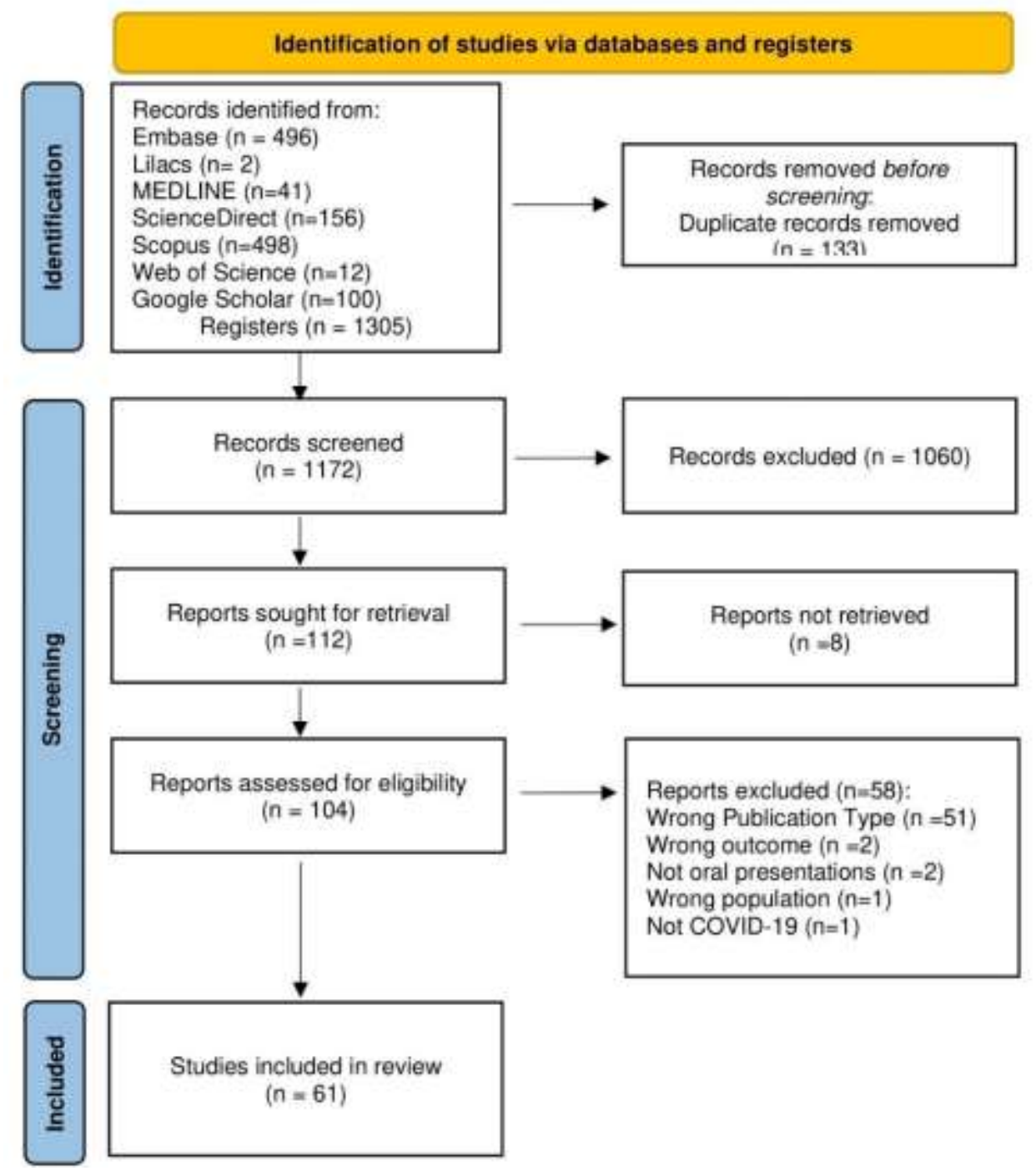

Source: Authors.

\section{Discussion}

More than 206.757 patients were considered in this review and there was a wide variation in the audience analyzed, probably due to the large variability of studies included, from case reports (Amorim Dos Santos et al., 2021; Amorim dos Santos et al., 2020a; Cebeci Kahraman, Özen, et al., 2020; Cherif et al., 2020; Chern et al., 2020; Cirillo et al., 2021b; Cruz Tapia et al., 2020; Eghbali Zarch \& Hosseinzadeh, 2021b; Kitakawa et al., 2020b; Moreira et al., 2020b; Ramires et al., 2021) to clinical studies (Karadas et al., 2020; Marouf et al., 2021). There were no restrictions regarding the gender investigated by the studies, nor were there any discrepancies regarding this information to the course of the disease, clinical manifestations or even the severity of the outcome found. Age was also a factor considered in some investigations, although it did not interfere in the course of COVID either (Bao et al., 2020; Cebeci Kahraman, Özen, et al., 2020; Cirillo et al., 2021b; Coke et al., 2021b; Larvin et al., 2020b).

The aim and conduct of each study also varied a lot, which diversifies the findings and how each one was carried out. While some focused on biomolecular (L. Chen et al., 2020a; Fernandes Matuck et al., 2020) others emphasized the clinical 
aspects and aspects of the disease itself, its possible associations and its consequences (Amorim Dos Santos et al., 2021; Amorim dos Santos et al., 2020a; Cebeci Kahraman, Özen, et al., 2020; Lechien et al., 2020a; Manzalawi et al., 2020; M. MousaviHasanzadeh et al., 2020; Pang et al., 2020).

Although among the studies that clinically addressed COVID-19, the most used form of diagnosis was RT-PCR in the detection of viral RNA, the serological analysis also was used in the detection of IgG and IgM antibodies (Amorim Dos Santos et al., 2021; Amorim Dos Santos et al., 2020b; Brandao et al., 2021; Cebeci Kahraman, Ozen, et al., 2020; L. Chen et al., 2020b; Cherif et al., 2020; Cirillo et al., 2021a; Coke et al., 2021a; Cruz Tapia et al., 2020; Eghbali Zarch \& Hosseinzadeh, 2021a; Elibol, 2021; Fantozzi et al., 2020; Fernandes Matuck et al., 2020; Fidan et al., 2021; Freni et al., 2020; Gherlone et al., 2021; Halboub et al., 2020; Hockova et al., 2021; Karadas et al., 2020; Kitakawa et al., 2020a; Lechien et al., 2020b; Moreira et al., 2020a; Morteza Mousavi-Hasanzadeh et al., 2020; Nitecki et al., 2021; Ramires et al., 2021; Saniasiaya et al., 2021; Sheng et al., 2021; Sirin \& Ozcelik, 2021; Tham et al., 2021). Sputum and saliva analysis, nasal and throat smears were also used (Bao et al., 2020; Cherif et al., 2020; Coke et al., 2021a). A localized article also considered the presence of taste disorders as a way of diagnosing this condition (Cirillo et al., 2021a).

Another variable investigated by some authors was the previous health conditions of the patients who composed the samples, with systemic alterations being mentioned chronic obstructive pulmonary disease (Bao et al., 2020; Brandao et al., 2021; Elibol, 2021; Fantozzi et al., 2020; Gherlone et al., 2021; Larvin et al., 2020a; Sirin \& Ozcelik, 2021), diabetes mellitus (Bao et al., 2020; Biadsee et al., 2020; Brandao et al., 2021; Chern et al., 2020; Coke et al., 2021a; Fantozzi et al., 2020; Fernandes Matuck et al., 2020; Freni et al., 2020; Gherlone et al., 2021; Halboub et al., 2020; Lovato \& de Filippis, 2020; Marouf et al., 2021; Ramires et al., 2021; Sirin \& Ozcelik, 2021), arterial hypertension (Amorim Dos Santos et al., 2021; Bao et al., 2020; Biadsee et al., 2020; Brandao et al., 2021; Chern et al., 2020; Coke et al., 2021a; Eghbali Zarch \& Hosseinzadeh, 2021a; Elibol, 2021; Fantozzi et al., 2020; Fernandes Matuck et al., 2020; Freni et al., 2020; Halboub et al., 2020; Hockova et al., 2021; Larvin et al., 2020a; Lovato \& de Filippis, 2020; Nitecki et al., 2021; Ramires et al., 2021; Sirin \& Ozcelik, 2021), cancer (Coke et al., 2021a; Fantozzi et al., 2020; Fernandes Matuck et al., 2020; Gherlone et al., 2021; Sirin \& Ozcelik, 2021), heart diseases (Amorim Dos Santos et al., 2020b; Coke et al., 2021a; Elibol, 2021; Fantozzi et al., 2020; Fernandes Matuck et al., 2020; Gherlone et al., 2021; Lovato \& de Filippis, 2020; Moreira et al., 2020a), obesity (Brandao et al., 2021; Coke et al., 2021a; Freni et al., 2020; Hockova et al., 2021; Ramires et al., 2021), kidney problems (Amorim Dos Santos et al., 2021; Amorim Dos Santos et al., 2020b; Brandao et al., 2021; Gherlone et al., 2021; Halboub et al., 2020), hypothyroidism (Biadsee et al., 2020; Chern et al., 2020; Freni et al., 2020; Sirin \& Ozcelik, 2021), gastroesophageal reflux disease (Chern et al., 2020; Freni et al., 2020), asthma (Biadsee et al., 2020; Elibol, 2021; Fernandes Matuck et al., 2020; Freni et al., 2020; Nitecki et al., 2021; Sirin \& Ozcelik, 2021; Tham et al., 2021) and allergic rhinitis (Freni et al., 2020; Nitecki et al., 2021; Tham et al., 2021). Other conditions, which were less mentioned, are described in the Supplementary Table 1.

It is interesting to note that a higher prevalence of these comorbidities in patients affected by COVID-19 is not a mere coincidence (Iranmanesh et al., 2021b), since some of these conditions, such as heart disease, hypertension, diabetes and chronic inflammatory diseases, were associated with a worse prognosis of this pathology (Coke et al., 2021a; Larvin et al., 2020a). In the case of hypertension, what can justify the relationship is the use of drugs that inhibit the Angiotensin-Converting Enzyme 2 (ACE-2) which is considered one of the main ways of viral dissemination throughout the body. In this way, a progression of the virus would be facilitated, resulting in a more severe manifestation of the infection. Diabetes would have the development and worsening of this condition facilitated due to hyperglycemia-induced by this pathology that facilitates the entry of the virus into the cells, generating a greater number of contaminated cells, and consequently greater systemic damage (Coke et al., 2021a). Patients with COVID-19 may present asymptomatically or even with mild symptoms, which may progress to severe cases (Fathi et al., 2021; Halboub et al., 2020; Iranmanesh et al., 2021b; Jayasrikrupaa et al., 2020; Kitakawa et al., 2020a; La Rosa et al., 
2020; Mahmoud et al., 2021). The main symptoms associated with COVID-19 include fever, cough, myalgia, fatigue and dyspnea that usually appear five days after infection (Brandini et al., 2021; Karadas et al., 2020; Morteza Mousavi-Hasanzadeh et al., 2020). However, symptoms such as headache, gastrointestinal changes, runny nose and cough have also been associated with this infection. The most severe cases of this contamination evolve to a severe acute respiratory syndrome which, due to complications in the course of the disease, progress to multiple organ failure and finally to death (Coke et al., 2021a; Elibol, 2020; Jayasrikrupaa et al., 2020; Maciel et al., 2020; Sinjari, D'Ardes, et al., 2020).

The studies included in this review mentioned as symptoms of COVID-19: anosmia (Cirillo et al., 2021a; Cruz Tapia et al., 2020; Halboub et al., 2020; Jayasrikrupaa et al., 2020; Maciel et al., 2020; Passarelli, Lopez, et al., 2020; Pitak-Arnnop et al., 2021; Risso et al., 2020; Sahin et al., 2020), hyposmia (Cruz Tapia et al., 2020; Halboub et al., 2020; Maciel et al., 2020; Risso et al., 2020; Tanasa et al., 2020), fever (Amorim Dos Santos et al., 2020b; Bao et al., 2020; Brandao et al., 2021; L. Chen et al., 2020b; Chérif et al., 2020; Chern et al., 2020; Cirillo et al., 2021a; Coke et al., 2021a; Elibol, 2021; Fantozzi et al., 2020; Fathi et al., 2021; Freni et al., 2020; Halboub et al., 2020; Hocková et al., 2021; Karadas et al., 2020; Lechien et al., 2020b; Manzalawi et al., 2021; Moreira et al., 2020a; Morteza Mousavi-Hasanzadeh et al., 2020; Nitecki et al., 2021; Sheng et al., 2021; Tapia et al., 2020; Zarch \& Hosseinzadeh, 2021), fatigue (Bao et al., 2020; L. Chen et al., 2020b; Manzalawi et al., 2020; Nitecki et al., 2021), cough (Bao et al., 2020; Biadsee et al., 2020; Brandao et al., 2021; Chérif et al., 2020; Cirillo et al., 2021a; Coke et al., 2021a; Fantozzi et al., 2020; Freni et al., 2020; Hocková et al., 2021; Jayasrikrupaa et al., 2020; Lechien et al., 2020b; Morteza Mousavi-Hasanzadeh et al., 2020; Nitecki et al., 2021; Pitak-Arnnop et al., 2021; Sheng et al., 2021; Tham et al., 2020; Zarch \& Hosseinzadeh, 2021), dyspnea (Bao et al., 2020; Coke et al., 2021a), acute respiratory distress syndrome (Bao et al., 2020; Cruz Tapia et al., 2020; Jayasrikrupaa et al., 2020; Morteza Mousavi-Hasanzadeh et al., 2020; Mulcahy et al., 2020; Santos et al., 2021; Tham et al., 2020), multiple organ failure (Bao et al., 2020; Coke et al., 2021a; Mulcahy et al., 2020), bacterial complications in other respiratory viral infections (coinfections) (Bao et al., 2020; Cirillo et al., 2021a; Moreira et al., 2020a), myalgia (Biadsee et al., 2020; J. Chen et al., 2020; Chérif et al., 2020; Coke et al., 2021 a; Eghbali Zarch \& Hosseinzadeh, 2021a; Fantozzi et al., 2020; Halboub et al., 2020; Morteza Mousavi-Hasanzadeh et al., 2020), headache (Coke et al., 2021a; Cruz Tapia et al., 2020; Freni et al., 2020; Halboub et al., 2020; Jayasrikrupaa et al., 2020; Karadas et al., 2020; Kitakawa et al., 2020a; Lechien et al., 2020b; Manzalawi et al., 2020), diarrhea (Coke et al., 2021a; Eghbali Zarch \& Hosseinzadeh, 2021a; Freni et al., 2020; Sirin \& Ozcelik, 2021), runny nose (Coke et al., 2021a; Fantozzi et al., 2020; Jayasrikrupaa et al., 2020; Pitak-Arnnop et al., 2021), gastrointestinal complications (Brandao et al., 2021; Chérif et al., 2020; Coke et al., 2021a; dos Santos et al., 2021; Fathi et al., 2021; Freni et al., 2020; Lechien et al., 2020b; Maciel et al., 2020; Moreira et al., 2020a; Tham et al., 2020), cutaneous manifestations (Capocasale et al., 2021; Chérif et al., 2020; Drago et al., 2021; Fathi et al., 2021; Halboub et al., 2020; Hockova et al., 2021; Maciel et al., 2020), sore throat (Halboub et al., 2020; Kitakawa et al., 2020a), dyspnea (Brandao et al., 2021; dos Santos et al., 2021; Fantozzi et al., 2020; Halboub et al., 2020; Hockova et al., 2021; Moreira et al., 2020a; Ramires et al., 2021), conjunctivitis (Chérif et al., 2020; Maciel et al., 2020; Pitak-Arnnop et al., 2021), loss of appetite (Eghbali Zarch \& Hosseinzadeh, 2021a). Other less mentioned manifestations can be found in the Supplementary Table 1.

Although cases with atypical manifestations of this disease can be found (Halboub et al., 2020; Iranmanesh et al., 2021b) most cases have a common evolution, which includes the manifestation of SARS and the involvement of other organs (Halboub et al., 2020; Hockova et al., 2021; Iranmanesh et al., 2021b). Both the involvement of the respiratory system and the unusual expressions of the disease may be related to the distribution of Angiotensin-Converting Enzyme 2 (ACE-2) in the human body, which is considered the main functional receptor through which SARS-CoV-2 infects cells, generating manifestations in the respiratory, gastrointestinal, neurological and even cutaneous expressions, which may also be the mechanism responsible for the oral affections of this condition (La Rosa et al., 2021; Mahmoud et al., 2021; Pitak-Arnnop et al., 2021; Sinjari, D'Ardes, et al., 2020). 
It is worth noting that ACE2 plays an important role in blood pressure regulation. Thus, the disruption of the bloodbrain barrier can happen due to endothelial dysfunctions as a consequence of the evolution of COVID-19. Likewise, SARSCoV-2 can present neurological manifestations by direct or indirect mechanisms (Karadas et al., 2020; Pedrosa et al., 2020). Furthermore, the manifestations of infection in skeletal muscle can occur due to contamination of isolated muscle cells or due to the link between pro-inflammatory cytokines with ACE2 (Karadas et al., 2020; Pedrosa et al., 2020).

Finally, opportunistic infections of other microorganisms can also be favored during COVID-19 infection and, as a result, potentiate the identified symptoms and even worsen the disease prognosis (Jayasrikrupaa et al., 2020; Nitecki et al., 2021; Parra-Ortega \& Rodriguez-Ortega, 2021; Tham et al., 2020).

The majority of the included studies in this review investigates oral symptoms derived from taste/gustatory alterations (ageusia, hypogeusia or dysgeusia) (Ammar et al., 2020; Amorim Dos Santos et al., 2021; Amorim Dos Santos et al., 2020b; Biadsee et al., 2020; Brandao et al., 2021; Brandini et al., 2021; Capocasale et al., 2021; L. Chen et al., 2020b; Cirillo et al., 2021a; Coke et al., 2021a; Eghbali Zarch \& Hosseinzadeh, 2021a; Elibol, 2021; Fantozzi et al., 2020; Jayasrikrupaa et al., 2020; Karadas et al., 2020; Maciel et al., 2020; Morteza Mousavi-Hasanzadeh et al., 2020; Nitecki et al., 2021; Padre \& Mourao, 2020; Passarelli, Passarelli, et al., 2020; Pitak-Arnnop et al., 2021; Risso et al., 2020; Saniasiaya et al., 2020; Sheng et al., 2021; Sinjari, D'Ardes, et al., 2020; Tanasa et al., 2020), xerostomia (Amorim Dos Santos et al., 2020b; Biadsee et al., 2020; Brandini et al.; L. Chen et al., 2020b; Coke et al., 2021a; Eghbali Zarch \& Hosseinzadeh, 2021a; Fantozzi et al., 2020; Freni et al., 2020; Gherlone et al., 2021; Halboub et al., 2020; Jayasrikrupaa et al., 2020; Lechien et al., 2020b; Maciel et al., 2020; Pitak-Arnnop et al., 2021; Sinjari, D'Ardes, et al., 2020), as well the presence of ulcerative lesions in oral mucosa and lips (Amorim Dos Santos et al., 2021; Brandao et al., 2021; Brandini et al., 2021; Capocasale et al., 2021; Cebeci Kahraman, Ozen, et al., 2020; Chérif et al., 2020; Cruz Tapia et al., 2020; Drago et al., 2021; Eghbali Zarch \& Hosseinzadeh, 2021a; Fathi et al., 2021; Fidan et al., 2021; Halboub et al., 2020; Hockova et al., 2021; Iranmanesh et al., 2021b; Jayasrikrupaa et al., 2020; Kitakawa et al., 2020a; La Rosa et al., 2020; Maciel et al., 2020; Mulcahy et al., 2020; Pitak-Arnnop et al., 2021; Ramires et al., 2021). A few studies also bring gingivitis and periodontal alterations as oral manifestations of COVID-19 though (Brandini et al., 2021; Coke et al., 2021a; Drago et al., 2021; Eghbali Zarch \& Hosseinzadeh, 2021a; Elibol, 2021; Larvin et al., 2020a; Maciel et al., 2020; Manzalawi et al., 2020; Marouf et al., 2021; Pitak-Arnnop et al., 2021). Minor reports of other lesions and affections are described in the Supplementary Table 1.

Even though gustatory impairments don't represent a direct threat to oral health, they should be considered as an early symptom of value in the diagnosis of coronavirus. The included studies describe the loss of taste in different levels and times of manifestation (Cirillo et al., 2021a). Further, it is observed that in many cases the loss of taste could go along with the loss of smell (Brandini et al., 2021; Coke et al., 2021a; Morteza Mousavi-Hasanzadeh et al., 2020; Nitecki et al., 2021; Pitak-Arnnop et al., 2021; Risso et al., 2020). Therefore, detecting this kind of symptom could be valuable during anamnesis for possible positive COVID-19 cases (Cirillo et al., 2021a; Elibol, 2021).

Another important finding in COVID-19 positive patients is xerostomia. It has been proved that salivary glands act as a reservoir of the virus, leading to contamination by saliva droplets and affecting salivary flow (Biadsee et al., 2020; Sinjari, D'Ardes, et al., 2020). Even more, some included studies suggest that xerostomia has been associated with taste sensorial complaints, common in positive COVID-19 patients, not only by the role that saliva plays during chewing but also by the predilection of the virus for nervous tissues that affects gustatory papillae (Fantozzi et al., 2020; Karadas et al., 2020; Pedrosa et al., 2020). It's also well known how the low rate of saliva affects oral health and, because of it, how coronavirus might have influence, even temporarily, on oral affections and functions by the patient directly or indirectly (Coke et al., 2021a).

The presence of painful ulcerated or necrotic oral lesions is also described as a possible manifestation of coronavirus. The location, size and characteristics of the lesions vary in the included studies, been reported aphthous-like ulcers in the upper 
and lower lip mucosa as well as the anterior dorsal tongue (Brandao et al., 2021; Chérif et al., 2020) and small hemorrhagic blisters and ulcerations affecting the upper and lower lips, as well as focal areas of shallow necrosis on the anterior dorsal tongue (Drago et al., 2021). Other studies also describe painful hemorrhagic ulcers along the upper and lower lips, leading to a thickcrusted hemorrhagic necrosis covering the lips entirely (Cebeci Kahraman, Ozen, et al., 2020; Coke et al., 2021a; Cruz Tapia et al., 2020; Fathi et al., 2021; Hockova et al., 2021; Karadas et al., 2020; Kitakawa et al., 2020a) (ST1). Therefore, these lesions should be considered during the patient's complaints and oral examination as a possible manifestation of COVID-19.

The scientific literature describes how periodontal disease, oral infections and the lack of oral hygiene can affect cases of intubated patients, inducing aspiration pneumonia (Marouf et al., 2021). Conversely, included studies in this review also reported gingival bleeding, necrotizing gingivitis and worsening of periodontal disease in positive COVID-19 patients (Brandini et al., 2021; Coke et al., 2021a; Drago et al., 2021; Eghbali Zarch \& Hosseinzadeh, 2021a; Elibol, 2021; Larvin et al., 2020a; Maciel et al., 2020; Manzalawi et al., 2020; Marouf et al., 2021; Pitak-Arnnop et al., 2021). Although the interference mechanisms for COVID-19 in periodontal disease are not very sedimented yet, the occurrences might indicate a two-way path for these conditions to be explored in future studies where periodontitis can lead to aspiration pneumonia and the infection by COVID-19 can worst cases of gingivitis and periodontitis.

Minor reports and other oral conditions related to coronavirus were also reported in included studies of this review (ST1). In general, all reported oral manifestations and symptoms derived from COVID-19 are still under investigation by the international scientific community and future studies might show new interactions and mechanisms between the coronavirus and its influence in the stomatognathic system. Still there, the clinician needs to understand the possible manifestations of the disease to help in its diagnosis and treatment.

The majority of the studies informed a non-specific treatment for both interests: COVID-19 and the correlated oral manifestations. For the COVID-19, it is clear that there is no specific protocol of treatment. In general, the mild and moderate forms of the disease are treated with corticosteroids (hydrocortisone and dexamethasone), NSAIDs (Naproxen), antivirals (Rendemsivir, favipiravir, ribavirin, oseltamivir, lopinavir, ritonavir, acyclovir, and valacyclovir), and antibiotics (Azithromycin, Levofloxacin, cefuroxime, ceftriaxone, metronidazole, and meropenem) in association, or isolated (Brandao et al., 2021; Chérif et al., 2020; Coke et al., 2021a; Cruz Tapia et al., 2020; Eghbali Zarch \& Hosseinzadeh, 2021a; Fathi et al., 2021; Halboub et al., 2020; Iranmanesh et al., 2021b; Santos et al., 2020; Sinjari, D'Ardes, et al., 2020). This recommendation varied a lot. Some authors reported the administration of those principal medicines with a large range of other ones (nasal saline irrigation, hydroxychloroquine, chloroquine, diphenhydramine, acetaminophen, Vitamin B, dipyrone, and Fexofenadine) arbitrarily (Coke et al., 2021a; Halboub et al., 2020; Manzalawi et al., 2020; Morteza Mousavi-Hasanzadeh et al., 2020; Sheng et al., 2021; Tanasa et al., 2020). Taking into account that there are many strands in the therapy approach for COVID-19 a wide range of combinations of medicines were already expected to be observed.

For the oral manifestations, most of the studies have not informed the therapy applied. It leads to the guesswork that they were not treated separately from the suggested therapy for COVID-19. However, some interesting reports were observed. Two cases of phototherapy were reported: Ramires et al. (2021) have used photodynamic therapy for 2 days to treat crusted ulcers in the upper lip, that healed in 4 days; and Brandao et al. (2021) have used photobiomodulation associated with acyclovir daily, with complete resolution of aphthous-like ulcers in 11 days. Similarly, Cebeci Kahraman, Ozen, et al. (2020) has used Triticumvulgare extract, four times a day, with Subcutaneous low-molecular-weight heparin to treat hemorrhagic necrosis covering the lips, which was resolved in 10 days.

Other conventional treatments, such as the combination of antifungal and chlorhexidine for white plaques on tongue dorsum (dos Santos et al., 2021), removal of dental plaque (Fathi et al., 2021), oral palliative intervention, and oral hygiene (Cruz Tapia et al., 2020; Kitakawa et al., 2020a; Santos et al., 2021), a mouthwash of chlorhexidine and alcohol-free solutions (Brandao 
et al., 2021; Halboub et al., 2020; Iranmanesh et al., 2021b; Manzalawi et al., 2020) and none, with spontaneous resolution (dos Santos et al., 2021). For gustatory impairment and salivary glands, I-carnitine (Tanasa et al., 2020), sialagogues, warm compresses, and massage (Chern et al., 2020) were recommended.

Most importantly, all suggested therapies were successful, with few exceptions. It highlights the efficiency of the suggested therapies and the high chances of spontaneous healing of COVID-19 and the associated oral manifestations. Just three studies have reported some non-fully recovered patients in the follow-up (Coke et al., 2021a; Marouf et al., 2021; Tanasa et al., 2020), and with a non-expressive n. Some of those reports of non-recovering were also related to committed patients, with one or more comorbidities (Coke et al., 2021a). Long-lasting or persistent symptoms were also reported: gingival hyperpigmentation (Eghbali Zarch \& Hosseinzadeh, 2021a), olfactory and taste disorder (Tham et al., 2020), and burning mouth sensation (Cruz Tapia et al., 2020).

The time for oral manifestations related to the COVID-19 infection also varies from each study and symptom (Amorim Dos Santos et al., 2021; Brandão et al., 2020; Brandini et al., 2021; Capocasale et al., 2021; Cebeci Kahraman, Ozen, et al., 2020; L. Chen et al., 2020b; Cruz Tapia et al., 2020; Eghbali Zarch \& Hosseinzadeh, 2021a; Fantozzi et al., 2020; Fathi et al., 2021; Halboub et al., 2020; Iranmanesh et al., 2021b; Kitakawa et al., 2020a; La Rosa et al., 2020; Lechien et al., 2020b; Manzalawi et al., 2020; Ramires et al., 2021; Sheng et al., 2021; Tanasa et al., 2020). While the majority of the included studies describe a wide range period of onset for oral manifestations, from one to forty-two days (Eghbali Zarch \& Hosseinzadeh, 2021a; Sheng et al., 2021), some studies also report the onset of oral symptoms before diagnosis of COVID-19, been until seven days prior (Cebeci Kahraman, Ozen, et al., 2020; Cirillo et al., 2021a; Fantozzi et al., 2020; Iranmanesh et al., 2021b; Manzalawi et al., 2020). Gustatory dysfunctions, xerostomia, ulcerative lesions and periodontal alterations were described such before as after COVID-19 diagnosis confirmation and presence of other symptoms in this review. Finally, it is noteworthy that some studies describe sensorial impairments in the early stages of COVID-19, however, many of the included studies in the review report the cases from hospital admission, which may be responsible for such a difference in time for oral symptoms and manifestations appearance.

\section{Conclusion}

In conclusion, despite the large number of studies located in the literature on the subject, the diversity of methodologies, populations, objectives and approaches makes it difficult to conclude on it. However, it is well established that prevention is the best approach in these cases, when there is a failure in this objective, the early diagnosis is of great value for a better prognosis. Thus, although it is still early to establish a direct relationship between oral manifestations and COVID-19, dental surgeons must recognize the symptoms related to this condition in their offices and make the appropriate referrals. Finally, more studies are needed to establish the link between COVID-19 and Dentistry in the future.

\section{Acknowledgments}

The authors would like to thank the Tutorial Education Program in the Dentistry course at the Universidade Federal de Alfenas for the opportunity and support to the tutor teacher Marcela Filié Haddad in the realization of these and other studies.

\section{References}

Ali, I., \& Alharbi, O. M. L. (2020). COVID-19: Disease, management, treatment, and social impact. Sci Total Environ, 728, 138861. https://doi.org/10.1016/j.scitotenv.2020.138861

Alvi, M. M., Sivasankaran, S., \& Singh, M. (2020). Pharmacological and non-pharmacological efforts at prevention, mitigation, and treatment for COVID-19. J Drug Target, 28(7-8), 742-754. https://doi.org/10.1080/1061186X.2020.1793990 
Ammar, N., Aly, N. M., Folayan, M. O., Khader, Y., Virtanen, J. I., Al-Batayneh, O. B., Mohebbi, S. Z., Attia, S., Howaldt, H. P., Boettger, S., Maharani, D. A., Rahardjo, A., Khan, I., Madi, M., Rashwan, M., Pavlic, V., Cicmil, S., Choi, Y. H., Joury, E., Castillo, J. L., Noritake, K., Shamala, A., Galluccio, G., Polimeni, A., Phantumvanit, P., Mancino, D., Kim, J. B., Abdelsalam, M. M., Arheiam, A., Dama, M. A., Nyan, M., Hussein, I., Alkeshan, M. M., Vukovic, A. P., Iandolo, A., Kemoli, A. M., \& El Tantawi, M. (2020). Behavior change due to COVID-19 among dental academics - The theory of planned behavior: Stresses, worries, training, and pandemic severity [Article]. PLoS ONE, 15(9 September). https://doi.org/10.1371/journal.pone.0239961

Amorim Dos Santos, J., Normando, A. G. C., Carvalho da Silva, R. L., Acevedo, A. C., De Luca Canto, G., Sugaya, N., Santos-Silva, A. R., \& Guerra, E. N. S. (2021). Oral Manifestations in Patients with COVID-19: A Living Systematic Review. J Dent Res, 100(2), 141-154. https://doi.org/10.1177/0022034520957289

Amorim dos Santos, J., Normando, A. G. C., Carvalho da Silva, R. L., De Paula, R. M., Cembranel, A. C., Santos-Silva, A. R., \& Guerra, E. N. S. (2020a). Oral mucosal lesions in a COVID-19 patient: New signs or secondary manifestations? [Note]. International Journal of Infectious Diseases, 97, 326-328. https://doi.org/10.1016/j.jijid.2020.06.012

Amorim Dos Santos, J., Normando, A. G. C., Carvalho da Silva, R. L., De Paula, R. M., Cembranel, A. C., Santos-Silva, A. R., \& Guerra, E. N. S. (2020b). Oral mucosal lesions in a COVID-19 patient: New signs or secondary manifestations? Int J Infect Dis, 97, 326-328. https://doi.org/10.1016/j.ijid.2020.06.012

Bao, L., Zhang, C., Dong, J., Zhao, L., Li, Y., \& Sun, J. (2020). Oral Microbiome and SARS-CoV-2: Beware of Lung Co-infection. Front Microbiol, 11, 1840. https://doi.org/10.3389/fmicb.2020.01840

Biadsee, A., Biadsee, A., Kassem, F., Dagan, O., Masarwa, S., \& Ormianer, Z. (2020). Olfactory and Oral Manifestations of COVID-19: Sex-Related SymptomsA Potential Pathway to Early Diagnosis. Otolaryngol Head Neck Surg, 163(4), 722-728. https://doi.org/10.1177/0194599820934380

Brandao, T. B., Gueiros, L. A., Melo, T. S., Prado-Ribeiro, A. C., Nesrallah, A., Prado, G. V. B., Santos-Silva, A. R., \& Migliorati, C. A. (2021). Oral lesions in patients with SARS-CoV-2 infection: could the oral cavity be a target organ? Oral Surg Oral Med Oral Pathol Oral Radiol, 131(2), e45-e51. https://doi.org/10.1016/j.oooo.2020.07.014

Brandão, T. B., Migliorati, C. A., Vechiato-Filho, A. J., Silva, W. G., Prado Ribeiro, A. C., Parise-Junior, O., Kowalski, L. P., \& Santos-Silva, A. R. (2020). Strategic use of obturator prostheses for the rehabilitation of oral cancer patients during the COVID-19 pandemic [Article in Press]. Supportive Care in Cancer. https://doi.org/10.1007/s00520-020-05694-5

Brandini, D. A., Takamiya, A. S., Thakkar, P., Schaller, S., Rahat, R., \& Naqvi, A. R. Covid-19 and oral diseases: Crosstalk, synergy or association? Reviews in Medical Virology. https://doi.org/10.1002/rmv.2226

Brandini, D. A., Takamiya, A. S., Thakkar, P., Schaller, S., Rahat, R., \& Naqvi, A. R. (2021). Covid-19 and oral diseases: Crosstalk, synergy or association? Rev Med Virol. https://doi.org/10.1002/rmv.2226

Capocasale, G., Nocini, R., Faccioni, P., Donadello, D., Bertossi, D., Albanese, M., \& Zotti, F. (2021). How to deal with coronavirus disease 2019: A comprehensive narrative review about oral involvement of the disease. Clin Exp Dent Res, 7(1), 101-108. https://doi.org/10.1002/cre2.332

Cebeci Kahraman, F., Ozen, T., \& Elibol, T. (2020). Lip necrosis in a patient with paroxysmal nocturnal hemoglobinuria: Can it be triggered by COVID-19? J Cosmet Dermatol, 19(12), 3168-3170. https://doi.org/10.1111/jocd.13746

Cebeci Kahraman, F., Özen, T., \& Elibol, T. (2020). Lip necrosis in a patient with paroxysmal nocturnal hemoglobinuria: Can it be triggered by COVID-19? [Article]. Journal of Cosmetic Dermatology, 19(12), 3168-3170. https://doi.org/10.1111/jocd.13746

Chen, J., Zhang, Y., Zhang, X., Jiang, Y., \& Huang, Y. (2020). Ambient Temperature Is an Independent Risk Factor for Acute Tonsillitis Incidence [Article]. Ear, Nose and Throat Journal. https://doi.org/10.1177/0145561320984573

Chen, L., Zhao, J., Peng, J., Li, X., Deng, X., Geng, Z., Shen, Z., Guo, F., Zhang, Q., Jin, Y., Wang, L., \& Wang, S. (2020a). Detection of SARS-CoV-2 in saliva and characterization of oral symptoms in COVID-19 patients [Article]. Cell Proliferation, 53(12). https://doi.org/10.1111/cpr.12923

Chen, L., Zhao, J., Peng, J., Li, X., Deng, X., Geng, Z., Shen, Z., Guo, F., Zhang, Q., Jin, Y., Wang, L., \& Wang, S. (2020b). Detection of SARS-CoV-2 in saliva and characterization of oral symptoms in COVID-19 patients. Cell Prolif, 53(12), e12923. https://doi.org/10.1111/cpr.12923

Cherif, M. Y., de Filette, J. M. K., Andre, S., Kamgang, P., Richert, B., \& Clevenbergh, P. (2020). Coronavirus disease 2019-related Kawasaki-like disease in an adult: A case report. JAAD Case Rep, 6(8), 780-782. https://doi.org/10.1016/j.jdcr.2020.06.023

Chérif, M. Y., de Filette, J. M. K., André, S., Kamgang, P., Richert, B., \& Clevenbergh, P. (2020). Coronavirus disease 2019-related Kawasaki-like disease in an adult: A case report [Article]. JAAD Case Reports, 6(8), 780-782. https://doi.org/10.1016/j.jdcr.2020.06.023

Chern, A., Famuyide, A. O., Moonis, G., \& Lalwani, A. K. (2020). Sialadenitis: A Possible Early Manifestation of COVID-19. Laryngoscope, 130(11), 25952597. https://doi.org/10.1002/lary.29083

Cirillo, N., Bizzoca, M. E., Lo Muzio, E., Cazzolla, A. P., \& Lo Muzio, L. (2021a). Gustatory dysfunction in COVID-19 patients: a rapid systematic review on 27,687 cases. Acta Odontol Scand, 79(6), 418-425. https://doi.org/10.1080/00016357.2020.1869828 
Cirillo, N., Bizzoca, M. E., Lo Muzio, E., Cazzolla, A. P., \& Lo Muzio, L. (2021b). Gustatory dysfunction in COVID-19 patients: a rapid systematic review on 27,687 cases [Review]. Acta Odontologica Scandinavica. https://doi.org/10.1080/00016357.2020.1869828

Coke, C. J., Davison, B., Fields, N., Fletcher, J., Rollings, J., Roberson, L., Challagundla, K. B., Sampath, C., Cade, J., Farmer-Dixon, C., \& Gangula, P. R. (2021a). SARS-CoV-2 Infection and Oral Health: Therapeutic Opportunities and Challenges. J Clin Med, 10(1). https://doi.org/10.3390/jcm10010156

Coke, C. J., Davison, B., Fields, N., Fletcher, J., Rollings, J., Roberson, L., Challagundla, K. B., Sampath, C., Cade, J., Farmer-Dixon, C., \& Gangula, P. R. (2021b). SARS-CoV-2 infection and oral health: Therapeutic opportunities and challenges [Review]. Journal of Clinical Medicine, 10(1), 1-19. https://doi.org/10.3390/jcm10010156

Cruz Tapia, R. O., Peraza Labrador, A. J., Guimaraes, D. M., \& Matos Valdez, L. H. (2020). Oral mucosal lesions in patients with SARS-CoV-2 infection. Report of four cases. Are they a true sign of COVID-19 disease? Spec Care Dentist, 40(6), 555-560. https://doi.org/10.1111/scd.12520

dos Santos, M. B. F., Pires, A. L. C., Saporiti, J. M., Kinalski, M. D. A., \& Marchini, L. (2021). Impact of COVID-19 pandemic on oral health procedures provided by the Brazilian public health system: COVID-19 and oral health in Brazil. Health Policy and Technology, 10(1), 135-142. https://doi.org/https://doi.org/10.1016/j.hlpt.2021.02.001

Drago, F., Ciccarese, G., Merlo, G., Trave, I., Javor, S., Rebora, A., \& Parodi, A. (2021). Oral and cutaneous manifestations of viral and bacterial infections: Not only COVID-19 disease. Clinics in Dermatology. https://doi.org/10.1016/j.clindermatol.2021.01.021

Eghbali Zarch, R., \& Hosseinzadeh, P. (2021a). COVID-19 from the perspective of dentists: A case report and brief review of more than 170 cases. Dermatol Ther, 34(1), e14717. https://doi.org/10.1111/dth.14717

Eghbali Zarch, R., \& Hosseinzadeh, P. (2021b). COVID-19 from the perspective of dentists: A case report and brief review of more than 170 cases [Review]. Dermatologic Therapy, 34(1). https://doi.org/10.1111/dth.14717

Ejaz, H., Alsrhani, A., Zafar, A., Javed, H., Junaid, K., Abdalla, A. E., Abosalif, K. O. A., Ahmed, Z., \& Younas, S. (2020). COVID-19 and comorbidities: Deleterious impact on infected patients. J Infect Public Health, 13(12), 1833-1839. https://doi.org/10.1016/j.jiph.2020.07.014

Elibol, E. (2020). Otolaryngological symptoms in COVID-19 [Article in Press]. European Archives of Oto-Rhino-Laryngology. https://doi.org/10.1007/s00405020-06319-7

Elibol, E. (2021). Otolaryngological symptoms in COVID-19. Eur Arch Otorhinolaryngol, 278(4), 1233-1236. https://doi.org/10.1007/s00405-020-06319-7 Fantozzi, P. J., Pampena, E., Di Vanna, D., Pellegrino, E., Corbi, D., Mammucari, S., Alessi, F., Pampena, R., Bertazzoni, G., Minisola, S., Mastroianni, C. M., Polimeni, A., Romeo, U., \& Villa, A. (2020). Xerostomia, gustatory and olfactory dysfunctions in patients with COVID-19. Am J Otolaryngol, 41(6), 102721. https://doi.org/10.1016/j.amjoto.2020.102721

Fathi, Y., Hoseini, E. G., \& Mottaghi, R. (2021). Erythema multiform-like lesions in a patient infected with SARS-CoV-2: A case report [Article]. Future Virology, 16(3), 157-160. https://doi.org/10.2217/fvl-2020-0333

Fernandes Matuck, B., Dolhnikoff, M., Maia, G. V. A., Isaac Sendyk, D., Zarpellon, A., Costa Gomes, S., Duarte-Neto, A. N., Rebello Pinho, J. R., GomesGouvea, M. S., Sousa, S., Mauad, T., Saldiva, P., Braz-Silva, P. H., \& da Silva, L. F. F. (2020). Periodontal tissues are targets for Sars-Cov-2: a post-mortem study. J Oral Microbiol, 13(1), 1848135. https://doi.org/10.1080/20002297.2020.1848135

Fidan, V., Koyuncu, H., \& Akin, O. (2021). Oral lesions in Covid 19 positive patients. Am J Otolaryngol, 42(3), 102905. https://doi.org/10.1016/j.amjoto.2021.102905

Freni, F., Meduri, A., Gazia, F., Nicastro, V., Galletti, C., Aragona, P., Galletti, C., Galletti, B., \& Galletti, F. (2020). Symptomatology in head and neck district in coronavirus disease (COVID-19): A possible neuroinvasive action of SARS-CoV-2. Am J Otolaryngol, $41(5), \quad 102612$. https://doi.org/10.1016/j.amjoto.2020.102612

Gherlone, E. F., Polizzi, E., Tete, G., De Lorenzo, R., Magnaghi, C., Rovere Querini, P., \& Ciceri, F. (2021). Frequent and Persistent Salivary Gland Ectasia and Oral Disease After COVID-19. J Dent Res, 100(5), 464-471. https://doi.org/10.1177/0022034521997112

Guan, W. J., Ni, Z. Y., Hu, Y., Liang, W. H., Ou, C. Q., He, J. X., Liu, L., Shan, H., Lei, C. L., Hui, D. S. C., Du, B., Li, L. J., Zeng, G., Yuen, K. Y., Chen, R. C., Tang, C. L., Wang, T., Chen, P. Y., Xiang, J., Li, S. Y., Wang, J. L., Liang, Z. J., Peng, Y. X., Wei, L., Liu, Y., Hu, Y. H., Peng, P., Wang, J. M., Liu, J. Y., Chen, Z., Li, G., Zheng, Z. J., Qiu, S. Q., Luo, J., Ye, C. J., Zhu, S. Y., Zhong, N. S., \& China Medical Treatment Expert Group for, C. (2020). Clinical Characteristics of Coronavirus Disease 2019 in China. N Engl J Med, 382(18), 1708-1720. https://doi.org/10.1056/NEJMoa2002032

Halboub, E., Al-Maweri, S. A., Alanazi, R. H., Qaid, N. M., \& Abdulrab, S. (2020). Orofacial manifestations of COVID-19: a brief review of the published literature. Braz Oral Res, 34, e124. https://doi.org/10.1590/1807-3107bor-2020.vol34.0124

Hendren, N. S., Drazner, M. H., Bozkurt, B., \& Cooper, L. T., Jr. (2020). Description and Proposed Management of the Acute COVID-19 Cardiovascular Syndrome. Circulation, 141(23), 1903-1914. https://doi.org/10.1161/CIRCULATIONAHA.120.047349 
Hockova, B., Riad, A., Valky, J., Sulajova, Z., Stebel, A., Slavik, R., Beckova, Z., Pokorna, A., Klugarova, J., \& Klugar, M. (2021). Oral Complications of ICU Patients with COVID-19: Case-Series and Review of Two Hundred Ten Cases. J Clin Med, 10(4). https://doi.org/10.3390/jcm10040581

Hocková, B., Riad, A., Valky, J., Šulajová, Z., Stebel, A., Slávik, R., Bečková, Z., Pokorná, A., Klugarová, J., \& Klugar, M. (2021). Oral complications of ICU patients with COVID-19: Case-series and review of two hundred ten cases [Review]. Journal of Clinical Medicine, 10(4), 1-13. https://doi.org/10.3390/jcm10040581

Huang, C., Wang, Y., Li, X., Ren, L., Zhao, J., Hu, Y., Zhang, L., Fan, G., Xu, J., Gu, X., Cheng, Z., Yu, T., Xia, J., Wei, Y., Wu, W., Xie, X., Yin, W., Li, H., Liu, M., Xiao, Y., Gao, H., Guo, L., Xie, J., Wang, G., Jiang, R., Gao, Z., Jin, Q., Wang, J., \& Cao, B. (2020). Clinical features of patients infected with 2019 novel coronavirus in Wuhan, China. Lancet, 395(10223), 497-506. https://doi.org/10.1016/S0140-6736(20)30183-5

Iranmanesh, B., Khalili, M., Amiri, R., Zartab, H., \& Aflatoonian, M. (2021a). Oral manifestations of COVID-19 disease: A review article [Review]. Dermatologic Therapy, 34(1). https://doi.org/10.1111/dth.14578

Iranmanesh, B., Khalili, M., Amiri, R., Zartab, H., \& Aflatoonian, M. (2021b). Oral manifestations of COVID-19 disease: A review article. Dermatol Ther, 34(1), e14578. https://doi.org/10.1111/dth.14578

Jayasrikrupaa, R., Rajesh, E., \& Masthan, K. M. K. (2020). Oral cues in covid 19: Primary or secondary challenge [Article]. European Journal of Molecular and Clinical Medicine, 7(10), 800-804. https://www.embase.com/search/results?subaction=viewrecord\&id=L2010489325\&from=export

Karadas, O., Ozturk, B., \& Sonkaya, A. R. (2020). A prospective clinical study of detailed neurological manifestations in patients with COVID-19. Neurol Sci, 41(8), 1991-1995. https://doi.org/10.1007/s10072-020-04547-7

Khan, S., Liu, J., \& Xue, M. (2020). Transmission of SARS-CoV-2, Required Developments in Research and Associated Public Health Concerns. Front Med (Lausanne), 7, 310. https://doi.org/10.3389/fmed.2020.00310

Kitakawa, D., Oliveira, F. E., Neves de Castro, P., \& Carvalho, L. (2020a). Short report - Herpes simplex lesion in the lip semimucosa in a COVID-19 patient. Eur Rev Med Pharmacol Sci, 24(17), 9151-9153. https://doi.org/10.26355/eurrev_202009_22863

Kitakawa, D., Oliveira, F. E., Neves De Castro, P., \& Carvalho, L. F. C. S. (2020b). Short report - Herpes simplex lesion in the lip semimucosa in a COVID-19 patient [Article]. European Review for Medical and Pharmacological Sciences, 24(17), 9151-9153. https://doi.org/10.26355/eurrev_202009_22863

La Rosa, G. R. M., Libra, M., De Pasquale, R., Ferlito, S., \& Pedulla, E. (2020). Association of Viral Infections With Oral Cavity Lesions: Role of SARS-CoV2 Infection. Front Med (Lausanne), 7, 571214. https://doi.org/10.3389/fmed.2020.571214

La Rosa, G. R. M., Libra, M., De Pasquale, R., Ferlito, S., \& Pedullà, E. (2021). Association of Viral Infections With Oral Cavity Lesions: Role of SARS-CoV2 Infection [Review]. Frontiers in Medicine, 7, Article 571214. https://doi.org/10.3389/fmed.2020.571214

Lai, J., Ma, S., Wang, Y., Cai, Z., Hu, J., Wei, N., Wu, J., Du, H., Chen, T., Li, R., Tan, H., Kang, L., Yao, L., Huang, M., Wang, H., Wang, G., Liu, Z., \& Hu, S. (2020). Factors Associated With Mental Health Outcomes Among Health Care Workers Exposed to Coronavirus Disease 2019. JAMA Netw Open, 3(3), e203976. https://doi.org/10.1001/jamanetworkopen.2020.3976

Larvin, H., Wilmott, S., Wu, J., \& Kang, J. (2020a). The Impact of Periodontal Disease on Hospital Admission and Mortality During COVID-19 Pandemic. Front Med (Lausanne), 7, 604980. https://doi.org/10.3389/fmed.2020.604980

Larvin, H., Wilmott, S., Wu, J., \& Kang, J. (2020b). The Impact of Periodontal Disease on Hospital Admission and Mortality During COVID-19 Pandemic [Article]. Frontiers in Medicine, 7. https://doi.org/10.3389/fmed.2020.604980

Lechien, J. R., Chetrit, A., Chekkoury-Idrissi, Y., Distinguin, L., Circiu, M., Saussez, S., Berradja, N., Edjlali, M., Hans, S., \& Carlier, R. (2020a). Parotitis-Like symptoms associated with COVID-19, France, March-April 2020 [Article]. Emerging Infectious Diseases, 26(9), 2270-2271. https://doi.org/10.3201/eid2609.202059

Lechien, J. R., Chetrit, A., Chekkoury-Idrissi, Y., Distinguin, L., Circiu, M., Saussez, S., Berradja, N., Edjlali, M., Hans, S., \& Carlier, R. (2020b). ParotitisLike Symptoms Associated with COVID-19, France, March-April 2020. Emerg Infect Dis, 26(9). https://doi.org/10.3201/eid2609.202059

Long, Q. X., Liu, B. Z., Deng, H. J., Wu, G. C., Deng, K., Chen, Y. K., Liao, P., Qiu, J. F., Lin, Y., Cai, X. F., Wang, D. Q., Hu, Y., Ren, J. H., Tang, N., Xu, Y. Y., Yu, L. H., Mo, Z., Gong, F., Zhang, X. L., Tian, W. G., Hu, L., Zhang, X. X., Xiang, J. L., Du, H. X., Liu, H. W., Lang, C. H., Luo, X. H., Wu, S. B., Cui, X. P., Zhou, Z., Zhu, M. M., Wang, J., Xue, C. J., Li, X. F., Wang, L., Li, Z. J., Wang, K., Niu, C. C., Yang, Q. J., Tang, X. J., Zhang, Y., Liu, X. M., Li, J. J., Zhang, D. C., Zhang, F., Liu, P., Yuan, J., Li, Q., Hu, J. L., Chen, J., \& Huang, A. L. (2020). Antibody responses to SARS-CoV-2 in patients with COVID19. Nat Med, 26(6), 845-848. https://doi.org/10.1038/s41591-020-0897-1

Lovato, A., \& de Filippis, C. (2020). Clinical Presentation of COVID-19: A Systematic Review Focusing on Upper Airway Symptoms. Ear Nose Throat J, 99(9), 569-576. https://doi.org/10.1177/0145561320920762 
Maciel, P. P., Martelli Júnior, H., Martelli, D. R. B., Machado, R. A., Andrade, P. V. d., Perez, D. E. d. C., \& Bonan, P. R. F. (2020). COVID-19 Pandemic: Oral Repercussions and its Possible Impact on Oral Health. Pesquisa Brasileira em Odontopediatria e Clínica Integrada, 20(suppl 1). https://doi.org/10.1590/pboci.2020.135

Mahmoud, M. M., Abuohashish, H. M., Khairy, D. A., Bugshan, A. S., Khan, A. M., \& Moothedath, M. M. (2021). Pathogenesis of dysgeusia in COVID-19 patients: a scoping review. Eur Rev Med Pharmacol Sci, 25(2), 1114-1134. https://doi.org/10.26355/eurrev_202101_24683

Manzalawi, R., Alhmamey, K., \& Abdelrasoul, M. (2020). Gingival bleeding associated with COVID-19 infection. Clin Case Rep. https://doi.org/10.1002/ccr3.3519

Manzalawi, R., Alhmamey, K., \& Abdelrasoul, M. (2021). Gingival bleeding associated with COVID-19 infection [Article]. Clinical Case Reports, 9(1), 294297. https://doi.org/10.1002/ccr3.3519

Mao, L., Jin, H., Wang, M., Hu, Y., Chen, S., He, Q., Chang, J., Hong, C., Zhou, Y., Wang, D., Miao, X., Li, Y., \& Hu, B. (2020). Neurologic Manifestations of Hospitalized Patients With Coronavirus Disease 2019 in Wuhan, China. JAMA Neurol, 77(6), 683-690. https://doi.org/10.1001/jamaneurol.2020.1127

Marouf, N., Cai, W., Said, K. N., Daas, H., Diab, H., Chinta, V. R., Hssain, A. A., Nicolau, B., Sanz, M., \& Tamimi, F. (2021). Association between periodontitis and severity of COVID-19 infection: A case-control study. J Clin Periodontol, 48(4), 483-491. https://doi.org/10.1111/jcpe.13435

Middeldorp, S., Coppens, M., van Haaps, T. F., Foppen, M., Vlaar, A. P., Muller, M. C. A., Bouman, C. C. S., Beenen, L. F. M., Kootte, R. S., Heijmans, J., Smits, L. P., Bonta, P. I., \& van Es, N. (2020). Incidence of venous thromboembolism in hospitalized patients with COVID-19. J Thromb Haemost, 18(8), 19952002. https://doi.org/10.1111/jth. 14888

Moreira, M. S., Neves, I. L. I., de Bernoche, C., Sarra, G., Dos Santos-Paul, M. A., Campos Neves da Silva, F., Schroter, G. T., Montano, T. C. P., de Carvalho, C. M. A., \& Neves, R. S. (2020a). Bilateral paresthesia associated with cardiovascular disease and COVID-19. Oral Dis. https://doi.org/10.1111/odi.13539

Moreira, M. S., Neves, I. L. I., de Bernoche, C. Y. S. M., Sarra, G., dos Santos-Paul, M. A., Campos Neves da Silva, F., Schroter, G. T., Montano, T. C. P., de Carvalho, C. M. A., \& Neves, R. S. (2020b). Bilateral paresthesia associated with cardiovascular disease and COVID-19 [Article]. Oral Diseases. https://doi.org/10.1111/odi.13539

Mousavi-Hasanzadeh, M., Sarmadian, H., Safi, F., Jamalian, M., \& Almasi-Hashiani, A. (2020). Epidemiological and clinical characteristics of patients with COVID-19 in Arak, Iran [Article]. Open Public Health Journal, 13(1), 712-717. https://doi.org/10.2174/1874944502013010712

Mousavi-Hasanzadeh, M., Sarmadian, H., Safi, F., Jamalian, M., \& Almasi-Hashiani, A. (2020). Epidemiological and Clinical Characteristics of Patients with COVID-19 in Arak, Iran. The Open Public Health Journal, 13(1), 712-717. https://doi.org/10.2174/1874944502013010712

Mulcahy, C. F., Ghulam-Smith, M., Mamidi, I. S., Thakkar, P. G., Edwards, H., Tummala, N., \& Tracy, L. F. (2020). Oropharyngeal hemorrhage in patients with COVID-19: A multi-institutional case series. Am J Otolaryngol, 41(6), 102691. https://doi.org/10.1016/j.amjoto.2020.102691

Nitecki, M., Taran, B., Ketko, I., Geva, G., Yosef, R., Toledo, I., Twig, G., Avramovitch, E., Gordon, B., Derazne, E., Fink, N., \& Furer, A. (2021). Self-reported symptoms in healthy young adults to predict potential coronavirus disease 2019. Clin Microbiol Infect, 27(4), 618-623. https://doi.org/10.1016/j.cmi.2020.12.028

Nuno-Gonzalez, A., Magaletsky, K., Feito Rodriguez, M., Mayor Ibarguren, A., Beato, M. J., Ruiz Bravo, E., \& Herranz Pinto, P. (2021). Palmoplantar erythrodysesthesia: a diagnostic sign of COVID-19. J Eur Acad Dermatol Venereol, 35(4), e247-e249. https://doi.org/10.1111/jdv.17074

Osseni, I. A. (2020). Benin responds to covid-19: sanitary cordon without generalized containment or lockdown? Trop Med Health, 48, 46. https://doi.org/10.1186/s41182-020-00235-6

Ouzzani, M., Hammady, H., Fedorowicz, Z., \& Elmagarmid, A. (2016). Rayyan-a web and mobile app for systematic reviews. Syst Rev, 5(1), 210. https://doi.org/10.1186/s13643-016-0384-4

Padre, A., \& Mourao, L. C. (2020). Correlation of Covid-19 With Stomatognathic System With Homeopathic Proposal for Adjunct Treatment to Increase Oral and General Health. Altern Ther Health Med, 26(S2), 112-116. http://www.ncbi.nlm.nih.gov/pubmed/33245703

Page, M. J., McKenzie, J. E., Bossuyt, P. M., Boutron, I., Hoffmann, T. C., Mulrow, C. D., Shamseer, L., Tetzlaff, J. M., Akl, E. A., Brennan, S. E., Chou, R., Glanville, J., Grimshaw, J. M., Hrobjartsson, A., Lalu, M. M., Li, T., Loder, E. W., Mayo-Wilson, E., McDonald, S., McGuinness, L. A., Stewart, L. A., Thomas, J., Tricco, A. C., Welch, V. A., Whiting, P., \& Moher, D. (2021). The PRISMA 2020 statement: an updated guideline for reporting systematic reviews. BMJ, 372, n71. https://doi.org/10.1136/bmj.n71

Pang, W., Zhang, D., Zhang, J., Li, N., Zheng, W., Wang, H., Liu, C., Yang, F., \& Pang, B. (2020). Tongue features of patients with coronavirus disease 2019: a retrospective cross-sectional study [Article]. Integrative Medicine Research, 9(3). https://doi.org/10.1016/j.imr.2020.100493

Parra-Ortega, I., \& Rodriguez-Ortega, D. (2021). SARS-CoV-2 impact on oral health: A general view. Bol Med Hosp Infant Mex, 78(2), 91-94. https://doi.org/10.24875/BMHIM.20000192 
Passarelli, P. C., Lopez, M. A., Mastandrea Bonaviri, G. N., Garcia-Godoy, F., \& D'Addona, A. (2020). Taste and smell as chemosensory dysfunctions in COVID-19 infection. Am J Dent, 33(3), 135-137. http://www.ncbi.nlm.nih.gov/pubmed/32470238

Passarelli, P. C., Passarelli, G., Charitos, I. A., Rella, E., Santacroce, L., \& D’Addona, A. (2020). COVID-19 and oral diseases: How can we manage hospitalized and quarantined patients while reducing risks? [Article]. Electronic Journal of General Medicine, 17(6). https://doi.org/10.29333/ejgm/7945

Pedrosa, M. D. S., Sipert, C. R., \& Nogueira, F. N. (2020). Salivary glands, saliva and oral findings in COVID-19 infection [Article]. Pesquisa Brasileira em Odontopediatria e Clinica Integrada, 20, 1-7, Article e0104. https://doi.org/10.1590/pboci.2020.112

Pitak-Arnnop, P., Meningaud, J. P., Sirintawat, N., Subbalekha, K., Auychai, P., Iamaroon, A., P, O. C., Suntorntham, S., Messer-Peti, R., \& Neff, A. (2021). A German AWMF's S2e/realist synthesis and meta-narrative snapshot of craniomaxillofacial manifestations in COVID-19 patients: Rapid living update on 1 January 2021. J Stomatol Oral Maxillofac Surg. https://doi.org/10.1016/j.jormas.2021.01.012

Ramires, M., Mattia, M. B., Tateno, R. Y., Palma, L. F., \& Campos, L. (2021). A combination of phototherapy modalities for extensive lip lesions in a patient with SARS-CoV-2 infection. Photodiagnosis Photodyn Ther, 33, 102196. https://doi.org/10.1016/j.pdpdt.2021.102196

Raoult, D., Zumla, A., Locatelli, F., Ippolito, G., \& Kroemer, G. (2020). Coronavirus infections: Epidemiological, clinical and immunological features and hypotheses. Cell Stress, 4(4), 66-75. https://doi.org/10.15698/cst2020.04.216

Risso, D., Drayna, D., \& Morini, G. (2020). Alteration, Reduction and Taste Loss: Main Causes and Potential Implications on Dietary Habits. Nutrients, 12(11). https://doi.org/10.3390/nu12113284

Sahin, M. M., Cebeci, S., Düzlü, M., Karamert, R., \& Ceylan, A. (2020). The effects of COVID-19 pandemic in otolaryngology practice: A review of the literature [Review]. Gazi Medical Journal, 31(2), 276-282. https://doi.org/10.12996/gmj.2020.70

Saniasiaya, J., Islam, M. A., \& Abdullah, B. (2020). Prevalence and Characteristics of Taste Disorders in Cases of COVID-19: A Meta-analysis of 29,349 Patients [Review]. Otolaryngology - Head and Neck Surgery (United States). https://doi.org/10.1177/0194599820981018

Saniasiaya, J., Islam, M. A., \& Abdullah, B. (2021). Prevalence and Characteristics of Taste Disorders in Cases of COVID-19: A Meta-analysis of 29,349 Patients. Otolaryngol Head Neck Surg, 165(1), 33-42. https://doi.org/10.1177/0194599820981018

Santos, B. S. D., Santos, F. S. D., \& Ribeiro, E. R. (2021). Clinical-Epidemiological Relation between Sars-Cov-2 and Kawasaki Disease: An Integrative Literature. Rev Paul Pediatr, 39, e2020217. https://doi.org/10.1590/1984-0462/2021/39/2020217

Santos, C., Filho, L., Santos, C. A. T., Neill, J. S., Vale, H. F., \& Kurnutala, L. N. (2020). [Pituitary tumor resection in a patient with SARS-CoV-2 (COVID19) infection. A case report and suggested airway management guidelines]. Rev Bras Anestesiol, 70(2), 165-170. https://doi.org/10.1016/j.bjan.2020.06.001

Sheng, W. H., Liu, W. D., Wang, J. T., Chang, S. Y., \& Chang, S. C. (2021). Dysosmia and dysgeusia in patients with COVID-19 in northern Taiwan. J Formos Med Assoc, 120(1 Pt 2), 311-317. https://doi.org/10.1016/j.jfma.2020.10.003

Sinjari, B., D'Ardes, D., Santilli, M., Rexhepi, I., D'Addazio, G., Di Carlo, P., Chiacchiaretta, P., Caputi, S., \& Cipollone, F. (2020). SARS-CoV-2 and Oral Manifestation: An Observational, Human Study. J Clin Med, 9(10). https://doi.org/10.3390/jcm9103218

Sinjari, B., D’ardes, D., Santilli, M., Rexhepi, I., D’addazio, G., Carlo, P. D., Chiacchiaretta, P., Caputi, S., \& Cipollone, F. (2020). SARS-CoV-2 and oral manifestation: An observational, human study [Article]. Journal of Clinical Medicine, 9(10), 1-14. https://doi.org/10.3390/jcm9103218

Sirin, D. A., \& Ozcelik, F. (2021). The relationship between COVID-19 and the dental damage stage determined by radiological examination. Oral Radiol. https://doi.org/10.1007/s11282-020-00497-0

Tanasa, I. A., Manciuc, C., Carauleanu, A., Navolan, D. B., Bohiltea, R. E., \& Nemescu, D. (2020). Anosmia and ageusia associated with coronavirus infection (COVID-19) - what is known? Exp Ther Med, 20(3), 2344-2347. https://doi.org/10.3892/etm.2020.8808

Tapia, R. O. C., Labrador, A. J. P., Guimaraes, D. M., \& Valdez, L. H. M. (2020). Oral mucosal lesions in patients with SARS-CoV-2 infection. Report of four cases. Are they a true sign of COVID-19 disease? Special Care in Dentistry, 40(6), 555-560. https://doi.org/10.1111/scd.12520

Tham, A. C., Thein, T. L., Lee, C. S., Tan, G. S. E., Manauis, C. M., Siow, J. K., Leo, Y. S., \& Lim, M. Y. (2020). Olfactory taste disorder as a presenting symptom of COVID-19: a large single-center Singapore study [Article in Press]. European Archives of Oto-Rhino-Laryngology. https://doi.org/10.1007/s00405020-06455-0

Tham, A. C., Thein, T. L., Lee, C. S., Tan, G. S. E., Manauis, C. M., Siow, J. K., Leo, Y. S., \& Lim, M. Y. (2021). Olfactory taste disorder as a presenting symptom of COVID-19: a large single-center Singapore study. Eur Arch Otorhinolaryngol, 278(6), 1853-1862. https://doi.org/10.1007/s00405-020-06455-0

Umakanthan, S., Sahu, P., Ranade, A. V., Bukelo, M. M., Rao, J. S., Abrahao-Machado, L. F., Dahal, S., Kumar, H., \& Kv, D. (2020). Origin, transmission, diagnosis and management of coronavirus disease 2019 (COVID-19). Postgrad Med J, 96(1142), 753-758. https://doi.org/10.1136/postgradmedj-2020-138234 
Research, Society and Development, v. 10, n. 14, e594101422516, 2021

(CC BY 4.0) | ISSN 2525-3409 | DOI: http://dx.doi.org/10.33448/rsd-v10i14.22516

Wiersinga, W. J., Rhodes, A., Cheng, A. C., Peacock, S. J., \& Prescott, H. C. (2020). Pathophysiology, Transmission, Diagnosis, and Treatment of Coronavirus Disease 2019 (COVID-19): A Review. JAMA, 324(8), 782-793. https://doi.org/10.1001/jama.2020.12839

Wilson, M. G., Hull, J. H., Rogers, J., Pollock, N., Dodd, M., Haines, J., Harris, S., Loosemore, M., Malhotra, A., Pieles, G., Shah, A., Taylor, L., Vyas, A., Haddad, F. S., \& Sharma, S. (2020). Cardiorespiratory considerations for return-to-play in elite athletes after COVID-19 infection: a practical guide for sport and exercise medicine physicians. Br J Sports Med, 54(19), 1157-1161. https://doi.org/10.1136/bjsports-2020-102710

Yang, L., Liu, S., Liu, J., Zhang, Z., Wan, X., Huang, B., Chen, Y., \& Zhang, Y. (2020). COVID-19: immunopathogenesis and Immunotherapeutics. Signal Transduct Target Ther, 5(1), 128. https://doi.org/10.1038/s41392-020-00243-2

Zarch, R. E., \& Hosseinzadeh, P. (2021). COVID-19 from the perspective of dentists: A case report and brief review of more than 170 cases. Dermatologic Therapy, 34(1), Article e14717. https://doi.org/10.1111/dth.14717

Zeng, F., Huang, Y., Guo, Y., Yin, M., Chen, X., Xiao, L., \& Deng, G. (2020). Association of inflammatory markers with the severity of COVID-19: A metaanalysis. Int J Infect Dis, 96, 467-474. https://doi.org/10.1016/j.ijid.2020.05.055 